\title{
Yumuşak doku kalsifikasyonları ve ossifikasyonları: derleme
}

\author{
Mehmet Özgür Özemre, ${ }^{*}$ Cansu Köseoğlu Seçgin, \\ Ayşe Gülşahı \\ Başkent Üniversitesi Diş Hekimliği Fakültesi, Ağız, Diş ve \\ Çene Radyolojisi Anabilim Dalı, Ankara, Türkiye
}

\section{Özet}

Normalde kemikte biriken minerallerin yumuşak dokuda birikmesi yumuşak doku kalsifikasyon/ossifikasyonları olarak bilinir. Genellikle asemptomatik olan bu kalsifikasyonlar daha çok ileri yaşta gözlenir. Sıklıkla radyografik değerlendirme sırasında tesadüfen saptanır. Bu tür kalsifikasyon/ossifikasyonlar ile karşılaşıldığında öncelikli amaç, kalsifikasyonu tanımak ve tedavi gerekip gerekmediğini belirlemektir. Doğru tanı için lokalizasyon, sayı, şekil gibi kriterlerin göz önüne alınması ve yumuşak doku anatomisinin iyi bilinmesi gereklidir. Ayrıca hastanın anamnez ve klinik muayenesini detaylandırmak veya gerekli ise farklı açıdan veya farklı teknikle ilave radyograf almak da faydalı olacaktır. Bu derlemenin amacı, yumuşak doku kalsifikasyon/ossifikasyonları konusundaki bilgileri, güncel literatür desteğiyle gözden geçirmektir.

Anahtar Kelimeler: Karotis arterleri; osifikasyon, heterotopik; panoramik radyografi; tükürük bezi taşı

KAYNAK GÖStermeK içiN: Özemre MÖ, Köseoğlu Seçgin C, Gülşahı A. Yumuşak doku kalsifikasyonları ve ossifikasyonları: derleme. Acta Odontol Turc 2016;33(3):166-75

EрітӧR: Zühre Akarslan, Gazi Üniversitesi, Ankara, Türkiye

YAYIN HAKKI: @ 2016 Özemre ve ark. Bu eserin yayın hakkı Creative Commons Attribution License ile ruhsatlandırılmıştır. Sınırsız kullanım, dağıtım ve her türlü ortamda çoğaltım, yazarlar ve kaynağın belirtilmesi kaydıyla serbesttir.

[Abstract in English is at the end of the manuscript]

\section{Giriş}

Normalde kemikte biriken kalsiyum tuzları, bazen yumuşak dokuda da birikebilir. Kalsiyum tuzlarının çökelmesi esas olarak kalsiyum fosfat şeklinde gerçekleşir. Minerallerin yumuşak dokuda organize olmadan birikmesi 'heterotopik kalsifikasyon' olarak adlandırılırken,

Makale gönderiliş tarihi: 05 Ağustos 2015; Yayına kabul tarihi: 07 Ocak 2016 *iletişim: Mehmet Özgür Özemre, Başkent Üniversitesi, Diş Hekimliği Fakültesi, Ağız, Diş ve Çene Radyolojisi Anabilim Dalı, 11. Sokak, Ňo: 26 Bahçelievler, Ankara, Türkiye

E-posta: mehmetozgurozemre@yahoo.com organize bir şekilde biriktiği durumlar ise 'heterotopik ossifikasyon' olarak bilinir. ${ }^{1-3}$

Yumuşak doku kalsifikasyonları/ossifikasyonları sıklıkla 40 yaş üzerindeki bireylerde gözlenir ancak çocuklarda gözlendiğine dair birkaç çalışma da mevcuttur., Kalsifikasyon veya ossifikasyonlar önemli bir belirti ya da semptoma neden olmaz. Genellikle radyografik muayene sırasında tesadüfen tespit edilir. ${ }^{6-10}$ Yumuşak doku kalsifikasyonlarının prevalansının \%2 ile \%5 arasında değiştiği bildirilmiştir. ${ }^{11-13}$

Yumuşak doku kalsifikasyonları tespit edildiğinde öncelikli amaç, kalsifikasyonu tanımak ve tedavi gerekip gerekmediğini belirlemektir. ${ }^{2,11,14,15}$ Doğru tanı için kalsifikasyonun lokalizasyon, sayı, şekil, dağılım gibi kriterlerinin göz önüne alınması gerekir. İlaveten yumuşak doku anatomisinin iyi bilinmesi de önemlidir. ${ }^{2,4} \mathrm{Bu}$ kalsifikasyonların ayırıcı tanısı, radyograflarda, hyoid kemik, triticeous kıkırdak, styloid proçes, epiglottis ve tiroid kıkırdağın üst boynuzları gibi anatomik yapılarla yapılmalıdır.,16,17 Yumuşak doku kalsifikasyonları kemiğe komşu olduğunda, kalsifikasyonun kemik içerisinde mi yoksa yumuşak dokuda mı olduğunu belirlemek zordur. Böyle durumlarda, hastanın anamnez ve klinik muayenesini detaylandırmak, farklı bir açıyla radyograf almak veya ileri görüntüleme tekniklerine başvurmak faydalı olabilir. ${ }^{2,11}$

Baş ve boyun bölgesinde en sık kalsifikasyon eğilimi olan yapılar, laringeal kıkırdaklar, vertebralar, arterler ve tiroid bezidir. ${ }^{15}$ Garay ve ark. ${ }^{4} 3028$ panoramik radyograf değerlendirdikleri çalışmasında; \%56 oranında tonsillolit, \%29 oranında karotid arter kalsifikasyonu, \%11 oranında siyalolit ve \%4 oranında kalsifiye lenf noduna rastlamışlardır. Monsour ve arkadaşlarının çalışmasında ise en sık karşılaşılan yumuşak doku kalsifikasyon/ ossifikasyonları; stylohyoid ligament ossifikasyonu, lenf nodu kalsifikasyonu ve siyalolit olarak belirlenmiştir. ${ }^{11}$

\section{HeterotopiK KaLSifiKASYON}

Heterotopik kalsifikasyonlar bulunduğu dokunun durumuna ve serum kalsiyum fosfat seviyelerine göre üç gruba ayrılır: 1) Distrofik kalsifikasyon, 2) İdiyopatik kalsifikasyon, 3) Metastatik kalsifikasyon ${ }^{1,2}$ 


\section{Distrofik kalsifikasyon}

Dejenere, hastalıklı veya ölü dokularda görülen distrofik kalsifikasyonda serum kalsiyum ve fosfat düzeyleri normaldir. ${ }^{1,2,8}$ Yumuşak dokudaki hasar, travma, enflamasyon, geçirilmiş hastalıklar, enjeksiyonlar, parazit varlığı gibi birçok nedenden kaynaklanabilir. Kalsifiye lenf nodu, tonsilolit, sistiserkozis ve arteriyel kalsifikasyonlar, bu gruptaki kalsifikasyon örneklerindendir. ${ }^{1,2}$

\section{Klinik özellikler}

Distrofik kalsifikasyonlar genellikle asemptomatiktir ancak nadiren üzerindeki yumuşak dokuda büyüme veya ülserasyon gözlenebilir. Bazı durumlarda sert bir kitle olarak palpe edilebilir. Sık görülen bölgeler dişeti, yumuşak damak, dil, lenf nodları ve yanaktır.

\section{Radyografik özellikler}

Distrofik kalsifikasyon radyografta, küçük, çok sayıda ince taneler şeklinde opasiteler olarak gözlenir. Çapı nadiren 0.5 cm'yi aşar, düzensiz radyoopak görüntü verir. Kalsifikasyon homojen olabileceği gibi noktalı alanlar da içerebilir. ${ }^{2}$

\section{Kalsifiye lenf nodları}

En yaygın gözlenen yumuşak doku kalsifikasyonlarından biri olan lenf nodu kalsifikasyonları başta granülamatöz hastalıklar olmak üzere çeşitli hastalıklar nedeniyle lenf bezlerindeki kronik enflamasyon sonucu oluşur. ${ }^{1-3,8}$ Lenf bezlerinde kalsifikasyon varlığı; aktif ya da geçirilmiş hastalığa işaret eder. ${ }^{2}$ Literatürde, tüberkülozda gözlenen lenf bezi kalsifikasyonlarının hem klinik hem de radyografik görüntüsü ile ilgili çok sayıda çalışma mevcuttur. ${ }^{3,8,18,19}$ Lenf nodu kalsifikasyonlarına neden olan diğer hastalıklar; sarkoidoz, sistemik skleroz, fungal enfeksiyonlar, romatoid artrit, kalsifiye neoplazmların metastazları ve radyoterapiyle tedavi edilmiş lenfomadır. ${ }^{2,8}$

Eisenkraft ve Som'un 2300 Bilgisayarlı Tomografi (BT) görüntüsünde servikal lenf nodlarını inceledikleri çalışmalarında \%1 oranında kalsifiye lenf noduna rastlanmıştır. ${ }^{20}$

\section{Klinik özellikler}

Genellikle asemptomatik seyirlidir. Radyografik muayene sırasında tesadüfen tespit edilir. Tek veya çok sayıda olabilir. Bu lenf nodları palpe edildiğinde sert, yumrulu ve yuvarlak kitleler olarak gözlenir., ${ }^{1,2,8}$

En sık tutulum gösteren lenf nodları submandibular ile derin ve yüzeyel servikal lenf nodlarıdır. Daha az sıklıkla etkilenenler ise preauriküler ve submental lenf nodlarıdır. ${ }^{2}$

Servikal ve submandibular bölgedeki kalsifiye lenf nodları ile dental problemlere bağlı olarak gelişen lenfadenopatiler karıştırılabilir. Bu durumda, klinik muayene ayırıcı tanıda çok önemlidir. ${ }^{19}$

\section{Radyografik özellikler}

En sık gözlendiği alan submandibular bölge olmakla birlikte, angulus bölgesinde mandibula alt kenarı altında veya üzerinde ya da servikal vertebralarla mandibular ramusun posterioru arasında gözlenir. ${ }^{1-3}$ Kalsifikasyonlar tek bir lenf nodunda olabileceği gibi 'lenf nodu zinciri' olarak adlandırılan bir dizi lenf nodunu etkileyebilir. ${ }^{2}$

Çevresi belirgin ve sıklıkla düzensizdir. Karnabahar benzeri lobüllü bir görüntü de verebilir (Resim 1). Bu düzensiz ve lobüllü yapısı, lenf nodu kalsifikasyonlarını diğer yumuşak doku kalsifikasyonlarından ayırt etmede büyük öneme sahiptir. ${ }^{2,8}$ Yuvarlak veya düzensiz kitle şeklinde görülen bu kalsifikasyonlar, değişen derecelerde radyoopasite içerir. Lezyon bazen tabakalı bir görünüme sahip olabilir ya da radyoopasite sadece lenf nodunun yüzeyinde görülebilir. Bu durum, 'yumurta kabuğu kalsifikasyonu' olarak adlandırıır. ${ }^{1,2}$

\section{Ayırıcı tanı}

Doğru tanıya ulaşabilmek için ilk önce yapılması gereken hastanın sistemik durumunu detaylı olarak sorgulamaktır. Tek bir kalsifiye lenf nodu ile submandibular bezdeki siyaloliti ayırt etmek zor olabilir. Çünkü her ikisi de mandibula angulus bölgesinde, mandibular korteksin altında veya üzerinde görüntü verebilir., ${ }^{2,3}$. Siyalolitlerin sıklıkla düzgün bir sınırı vardır ancak kalsifiye lenf nodları genellikle düzensiz bazen de lobludur. ${ }^{8}$ Ayrıca siyaIolitlerde semptom olması da ayırıcı tanıda önemlidir. ${ }^{1-3}$

Aynı bölgede gözlenen ve ayırıcı tanıda önemli olan bir diğer durum ise flebolittir. Flebolit, sıklıkla küçük ve çok sayıda radyoopak ya da radyolüsent halkalar şeklindedir. Bazen, bir kan damarını taklit eder bir görüntü şeklinde de gözlenebilir. ${ }^{1-3}$

Ayrıca, bu bölgede gözlenebilecek ve lenf nodu kalsifikasyonunu taklit edebilecek durumlardan olan stylohyoid ligament ossifikasyonu, osteoma cutis, sistiserkozis, osteomyelit, condensing osteitis, osteoma, odontoma ve fibröz displazi ile de ayırıcı tanı mutlaka yapılmalıdır. 3,7,14 Kalsifiye lenf nodları genellikle tedavi gerektirmez. Fakatözellikle aktif hastalık varlığında kalsifikasyonun altında yatan neden değerlendirilmelidir. ${ }^{1,2}$

\section{Tonsillerin distrofik kalsifikasyonu (tonsilolit)}

Tonsiller, sağ ve sol tarafta orofarinksin lateral duvarında bulunan lenfoid dokulardır. ${ }^{8}$ Tonsilolitler, tonsillerin kronik enflamasyonu sonucu oluşur., 1,7 Tekrarlayan

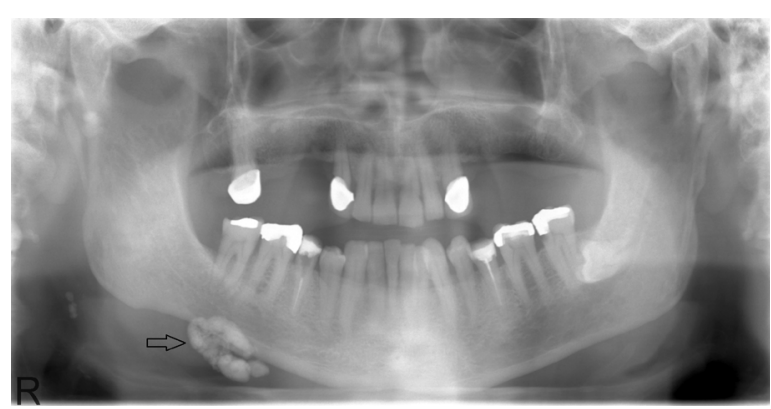

Resim 1. Panoramik radyografta sağ tarafta mandibula alt kenarına süperpoze olmuş, karnabahar şeklindeki submandibular lenf bezi kalsifikasyonu izlenmektedir (ok) 
enflamasyonlar sonucu tonsiller kriptalar genişler ve organik debrisin (ölü bakteriler ve cerahat, epitelyal hücreler ve yiyecekler) buralardaki retansiyonu kalsifikasyonun gelişmesine zemin hazırlar. ${ }^{2,8,10,21}$ Aspestrand ve Kolbenstvedt'in 100 hastanın panoramik radyografını değerlendirdikleri çalışmalarında tonsilolitlerin prevalansı \%16 olarak bulunmuştur. ${ }^{22}$ Centurion ve arkadaşlarının aynı hastalardan alınan Konik ışınlı Bilgisayarlı Tomografi (KIBT) ve panoramik radyograflarla yapmış olduğu bir çalışmada, KIBT ile saptanan tonsilolitlerin oranı \%27 iken, panoramik radyograflarda tespit edilenlerin oranı \%18 olarak bulunmuştur. Bu durum, üçboyutlu görüntülerin tanı kapasitelerinin daha yüksek olduğunun bir göstergesidir. ${ }^{7}$

\section{Klinik özellikler}

Çocuklarda oldukça nadir gözlenen tonsilolitler çoğunlukla ileri yaş grubunda ortaya çıkar. ${ }^{1,5}$ En sık 40’lı yaşlarda gözlenen tonsilolitler, klinikte sıklıkla sert, yuvarlak, beyaz ya da sarı renkte objeler olarak görülür. En sık palatinal tonsillerden olmak üzere tonsiller kriptalardan çıkıntı oluştururlar. Küçük kalsifikasyonlar çoğunlukla hiçbir klinik bulgu ve semptoma neden olmazken daha geniş kalsifikasyonlarda ağrı, şişlik, ağızda kötü koku, disfaji ve yutkunma esnasında yabancı cisim hissi yaratabilirler. ${ }^{2,5,8,10,21}$

\section{Radyografik özellikler}

Tonsilolitler panoramik radyograflarda dilin dorsal yüzeyinin ramusu çaprazladığı yerde, ramusun orta yüzeyine süperpoze olan, çok sayıda, küçük, pirinç tanesine benzer radyoopasiteler şeklinde görülür. 2,7,8,21 (Resim 2). Genellikle tek taraflı gözlense de iki taraflı da görülebilir. ${ }^{7}$ Sıklıkla karşı tarafta bir hayalet görüntüye neden olur. ${ }^{4}$ Nadiren büyük boyutlara ulaşabilir. Spongioz kemikten daha radyoopak, kortikal kemikle ise benzer radyoopasite gösterir. ${ }^{2}$

\section{Ayırıcı tanı}

Tonsilolitler nadir gözlenmesine rağmen, mandibular ramus üzerinde gözlenen radyoopak yapı söz konusu olduğunda ayırıcı tanıda düşünülmesi gereken durumlardandır. ${ }^{4}$ Siyalolit gibi patolojik kalsifikasyonlardan ayrımını yapmak oldukça önemlidir Ayrıca, sifiliz, lenfoma gibi granülamatöz hastalıklar da ayırıcı tanıda akla getirilmelidir. ${ }^{10}$ Temel radyografik ayırıcı tanı, mandibular ramusta kemik densitesine benzer opasite gösteren kitledir. Şüpheli durumlarda kalsifikasyonun lokalizasyonunu belirlemek için posteroanterior kafa grafisi veya Reverse town grafisi alınabilir.2

Çoğu tonsiller kalsifikasyon tedavi gerektirmez., ${ }^{1,2}$ Semptomları bulunan hastalarda tonsilolitler öğürme refleksini ortadan kaldırmak amacıyla çıkarılabilir. ${ }^{2}$

\section{Sistiserkozis}

Taenia solium yumurtalarının sindirim yoluna geçmesiyle, yumurtaların etrafındaki tabaka midede sindirilir ve parazitin larva formu oluşur. Larvalar mukozaya penetre olarak kan damarlarına ve lenfatiklere geçerek

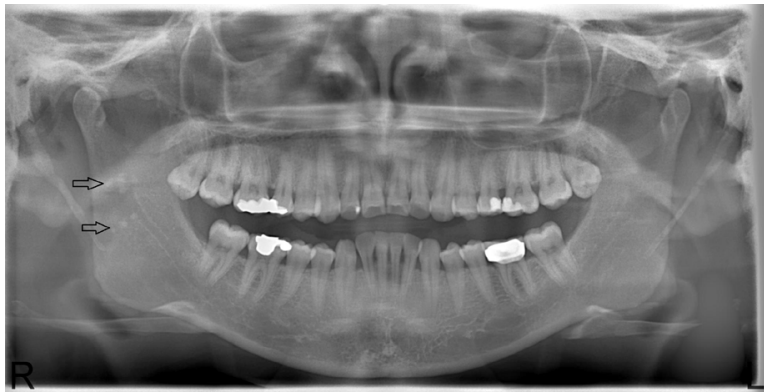

Resim 2. Panoramik radyografta sağ taraf ramus üzerine süperpoze olmuş, çok sayıda, yuvarlak tonsilolit Izlenmektedir (ok).

tüm vücut dokularına dağılır. Özellikle beyin, kas, deri, karaciğer, akciğerler ve kalbi tercih eder. Çiğneme kasları başta olmak üzere oral ve perioral dokularda da bulunur. Sindirim mukozası dışındaki dokularda larvalar ölür ve yabancı cisim reaksiyonu oluşturarak zamanla kalsifiye olur. Domuz tüketiminin ve tarımsal topraktan fokal kontaminasyonun olduğu gelişmekte olan ülkelerde bu durum daha fazla görülür. ${ }^{1,2}$

\section{Klinik özellikler}

Hafif vakalar tamamen asemptomatiktir. Ağır vakalarda epigastrik ağrı, mide bulantısı ve kusma ile başlayıp ölüme kadar giden komplikasyonlarla karşılaşılabilir. İntraoral muayenede çiğneme kaslarında, dilde, mukoza ve dudakta fluktasyon veren şişliklere rastlanabilir. ${ }^{1,2}$

\section{Radyografik özellikler}

Parazit hayattayken radyografta izlenemez. Parazitlerin ölümünden yıllar sonra subkutan dokularda ve kas dokularında oluşan kalsifikasyon, pirinç tanelerini andıran çok sayıda, iyi sınırlı, eliptik radyoopasiteler şeklinde izlenir. ${ }^{1,2}$

\section{Ayırıcı tanı}

Bazen siyalolitlere benzer görüntü verse de, küçük boyutlu nodüllerin beyin ve kaslarda yaygın bir şekilde gözlenmesi yüksek tanı kriteridir. Tedavide antiparazit ilaçlar kullanılır. ${ }^{1,2}$ Oral bölgede gelişen kalsifikasyonların bir zararı yoktur. Ancak başka bölgelerde meydana gelenler için detaylı inceleme gerekir.

\section{Arteriyel kalsifikasyonlar}

Arteriyel kalsifikasyonların radyolojik ve histolojik açıdan ayrımı yapılabilen iki ayrı formu vardır: Mönckeberg's medial kalsinozis (arteriosklerozis) ve kalsifiye aterosklerotik plak. ${ }^{1,2}$

\section{Mönckeberg's medial kalsinozis (arterioskleroz)}

Arterioskleroz, damarın medial tabakasında kalsiyum birikimi sonucu görülen parçalanma, dejenerasyon ve elastik fiberlerin kaybıdır., ${ }^{1,2}$ Arteriosklerozdan en sık internal ve eksternal karotid arterler etkilenirken vertebral ve lingual arterlerde de görülebilir. ${ }^{15}$

\section{Radyografik özellikler}

Kalsifiye damarlar, panoramik radyografta ince ve para- 


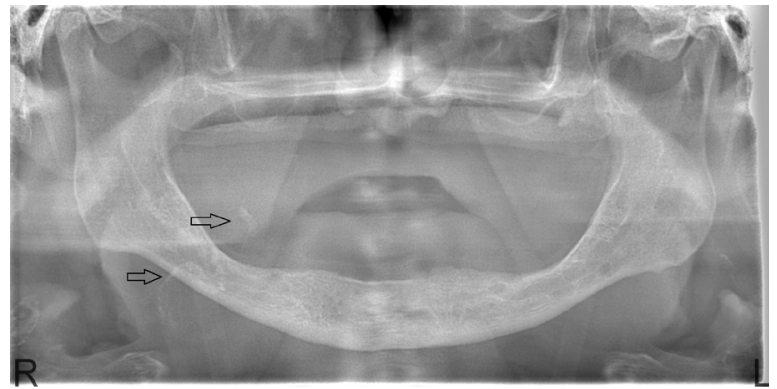

Resim 3. Panoramik radyografta sağ taraf mandibula korpusu üzerine süperpoze olmuş, aşağıdan yukarıya doğru seyreden radyoopak çizgi şeklinde arteriosklerozis izlenmektedir (ok).

lel bir çift radyoopak çizgi şeklinde görülür (Resim 3). ${ }^{2,8}$ Arteriosklerozun radyografik görüntüsü çok belirgin ve patognomoniktir.

Hastanın arterlerde tıkanmaya yol açan hastalıklar ve periferal vasküler hastalıklar açısından değerlendirilmesi gerekir. Ayrıca hiperparatiroidizm de akla getirilmelidir çünkü bu hastalığın görüldüğü bireylerde arterioskleroza sık rastlanır.²

\section{Kalsifiye aterosklerotik plak}

Kalsifiye aterosklerotik plak, etkilenen damarın intima tabakasında oluşan, serebrovasküler ve embolik hastalıklara neden olabilen aterosklerotik değişimlerin kalsifiye olması sonucu oluşur. 2,8,16,23

Literatürde son yıllarda yapılan birçok çalışmada, karotid arterin eksternal ve internal olarak ikiye ayrıldığı bölgede oluşan aterosklerotik plakların panoramik radyograflarda tespit edilebildiği ortaya konmuştur. 8,24,25 Elli yaş üzerindeki hastalarda panoramik radyograflarla tanısı konan karotid arter kalsifikasyonlarının prevalansının \%0.1 ile \%3.2 arasında değiştiğini gösteren çalışmalar mevcuttur. 8,17

Sisman ve arkadaşlarının ${ }^{26}$ Kapadokya bölgesinde kalsifiye aterosklerotik plak görülme sıklığını tespit etmek için 750 panoramik radyograf inceleyerek yaptığı çalışmada erkekler ve kadınlar arasında anlamlı bir fark bulunmamıştır. Bir diğer çalışmada ise 4106 panoramik radyograf incelenmiş ve kalsifiye aterosklerotik plakların kadınlarda daha yaygın gözlendiği tespit edilmiştir. ${ }^{27}$

Klinisyenlerin kalsifiye aterosklerotik plağı bölgedeki diğer anatomik ve patolojik radyoopasitelerden ayırt edebilmesi oldukça önemlidir. Bölgede radyoopak görüntü veren anatomik yapılar; hyoid kemik, epiglottis, stylomandibuler ligament ve stylohyoid ligamenttir. Benzer şekilde radyoopak görüntü veren patolojiler ise submandibuler siyalolitler, tonsilolit, flebolit ve kalsifiye lenf nodlarıdır. ${ }^{17,25}$ Aslında bu anatomik yapıların ve patolojilerin, konum veya morfolojileri itibarıyla kalsifiye aterosklerotik plaklarla ayrımı oldukça kolaydır. Ancak aterosklerotik plakların, kalsifiye triticeous kıkırdak veya kalsifiye tiroid kıkırdakla ayrımının yapılması önemlidir. ${ }^{8,17,28}$

\section{Radyografik özellikler}

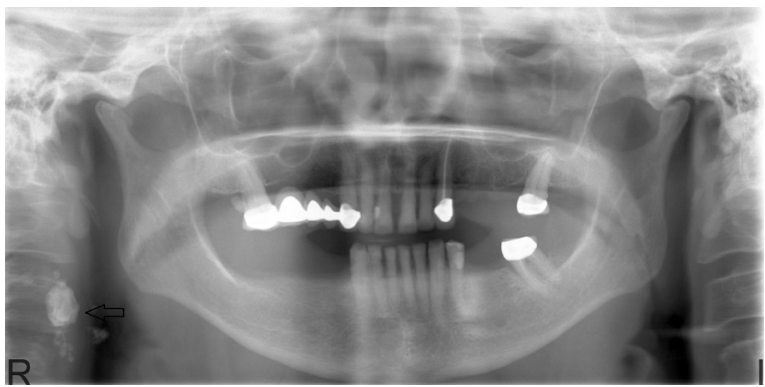

Resim 4. Panoramik radyografta sağda 3. servikal vertebra üzerine süperpoze olmuş düzensiz şekilli aterosklerotik plaklar izlenmektedir (ok).

Panoramik radyografta, hyoid kemiğin büyük boynuzunun altında veya üstünde sıklıkla 3 . ve 4 . servikal vertebralar arasında izlenir. Bu kalsifikasyonlar genellikle çok sayıda, düzensiz şekillidir ve heterojen radyoopakradyolüsent görüntü verir (Resim 4). Çevre yumuşak dokulardan keskin bir şekilde ayrılmıştır ve dikey çizgisel bir düzlemde görülür. 2,8,21,28

\section{Ayırıcı tanı}

Ayırıcı tanıda genellikle laringeal kıkırdak kalsifikasyonları düşünülür. Yanlış tanıya neden olan en önemli durum kalsifiye triticeous kıkırdaktır. Her ikisi de benzer bölgelerde görüntü oluştursa da kalsifiye aterosklerotik plak panoramik radyograflarda daha lateralde görünür. 8,16,17,28

Ahmad ve arkadaşlarının ${ }^{17}$ yapmış olduğu bir çalışmada kalsifiye aterosklerotik plakla, triticeous kıkırdak kalsifikasyonlarının boyutsal olarak da birbirine benzer olduğu ortaya konmuştur. Triticeous kıkırdak kalsifikasyonları genellikle iyi sınırlı, oval ve pürüzsüz bir yapı gösterirken, kalsifiye aterosklerotik plaklar çoğunlukla doğrusal veya ince dikdörtgenimsi yapıda ve sınırları düzensizdir.8,17 Benzer bölgede görüntü oluşturması nedeniyle ayırıcı tanısı yapılması gereken bir diğer durum da hyoid kemiktir. ${ }^{16}$

Panoramik radyografta, kalsifiye aterosklerotik plakla uyumlu kalsifikasyon tespit edilen hastaların serebrovasküler ve kardiyovasküler hastalıklar açısından ileri tetkikler için konsülte edilmesi oldukça önemlidir. ${ }^{8}$

\section{2. İdiyopatik kalsifikasyon}

Serum kalsiyum ve fosfat düzeyleri normal olmasına rağmen, kalsiyumun yumuşak dokularda depolanması sonucu gözlenen kalsifikasyonlardır. Baş ve boyun bölgesinde oldukça yaygındır. Siyalolit, flebolit, laringeal kıkırdak kalsifikasyonları ve antrolit-rinolit-dakriyolit bu tür kalsifikasyonlara örnektir.,

\section{Siyalolit}

Tükürük bezi veya kanal sisteminde gelişen kalsifiye yapılardır. Tükürük salgısının daha yavaş akımına sebep olan mekanik durumlar ve bez salgısının fizyokimyasal karakteristikleri, siyalolit oluşumuna zemin 
hazırlamakta ve kalsiyum fosfat tuzlarının birikmesine neden olmaktadır. ${ }^{1,2,8}$ Lee ve Kang'ın yapmış olduğu bir çalışmada 6,160 panoramik radyografta siyalolitlerin prevalansı $\% 0.1$ olarak bulunmuştur. ${ }^{29}$

\section{Klinik özellikler}

Çocuklarda ender rastlanan siyalolitlere sıklıkla orta ve ileri yaş grubundaki erkeklerde ve submandibular tükürük bezlerinde rastlanır. ${ }^{1,2}$ Çoğunlukla unilateral gözlenen siyalolitler yuvarlak veya oval yapıdadır. Farklı büyüklükte olabilmekle birlikte kanalın yüzeye yakın bölgelerinde ise palpasyonla hissedilebilir. Siyalolitler, tükürük bezi kanalında olabileceği gibi bez içerisinde de olabilir. Renkleri ise tipik olarak sarımsı beyaz veya sarımsı kahverengidir. ${ }^{1}$ Siyalolitler \%70-80 oranında tek olarak görülür fakat bazen özellikle parotis bezinde multiple olabilir. ${ }^{2}$

Siyalolitlerin bulunduğu bireylerde, sıklıkla ağız tabanında şişlik ve ağrı, etkilenen submandibular bezde ya da parotis kökenli ise yanakta ağrı hikayesi vardır. Tükürük akışının stimüle olduğu yemek sırasında bu rahatsızlık daha da şiddetlenebilir. Bez içerisindeki siyalolit, tükürük akımını genellikle tamamen engellemediğinden ağrı ve şişlik yavaş yavaş azalır. ${ }^{1,2,9}$ Kanal ağızları çoğunlukla eritemli görünümdedir. Sekonder enfeksiyon oluşursa ateş, kızarıklık ve kanaldan pürülan akıntı gözlenebilir. ${ }^{1}$ Siyalolit gözlenen hastaların \% 10'unda böbrek taşı hikayesi de vardır. ${ }^{2}$ Gut hastalığı olan bireylerde de siyalolitere sık rastlandığı bildirilmiştir. ${ }^{1}$

Siyalolitlerin \%83'ü submandibular, \%10'u parotis ve $\% 7$ 'si de sublingual bezde görülür. ${ }^{1,2,8}$ Literatürde minör tükürük bezlerinde siyalolit oluşumuna ilişkin bilgi ise oldukça sınırlıdır. ${ }^{1}$ Submandibular bezde siyalolitlerin çok görülmesi, bu bez salgısının daha visköz, mukustan daha zengin olması yanında kanalın dar, kısmen kıvrımlı, aşağıdan yukarıya bir seyir izlemesi ve kanal ağzının dar olması ile açıklanabilir. Ayrıca submandibular bezin sekresyonundaki kalsiyum miktarının, parotis salgısındakinin iki katı olması da siyalolitlerin bu bezde daha fazla olmasına neden olur. Submandibular bezdeki siyalolitler genellikle parotis bezindekilerden daha büyüktür. Ayrıca submandibular bezdeki siyalolitler tek, parotis bezindekiler genellikle birden çoktur. Submandibular siyalolitlerin \%70-80'i kanaldadır. ${ }^{1,2}$

Submandibular bezdeki siyalolitler, mandibular 1. molar dişlerin transvers yöndeki ilişkisine göre sınıflandırıldığında, bu hattın önünde kalanlar 'anterior', arkasında kalanlar 'posterior' olarak adlandırılır. ${ }^{1}$

\section{Radyografik özellikler}

Bazı siyalolitler homojen radyoopak yapıda iken bazıları radyoopak katmanlar şeklinde görüntü verir. Submandibular bezdeki siyalolitlerin \%20'den azı ve parotis bezindeki siyalolitlerin \%40'ı radyolüsent görüntü verir. Bunun sebebi parotis sekresyonunun daha düşük mineral içeriğine sahip olmasıdır. ${ }^{2}$

Submandibular bez kanalındaki siyalolitler sıklıkla

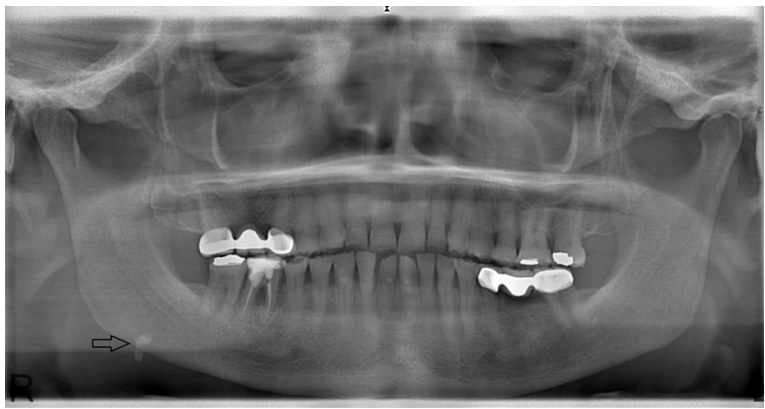

Resim 5. Panoramik radyografta sağ taraf mandibula korpusu üzerine süperpoze olmuş, düzgün yüzeyli silindir şeklinde submandibular siyalolit izlenmektedir (ok).

silindirik ve düzgün yüzeylidir (Resim 5). Bezin hilar kısmında bulunan siyalolitlerin ise daha büyük ve düzensiz olmaya meyilleri vardır. ${ }^{2,9}$ Tükürük bezi hastalıklarının tanısında oklüzal radyograf ve diğer konvansiyonel yöntemler, siyalografi, ultrasonografi, sintigrafi, bilgisayarlı tomografi, manyetik rezonans görüntüleme teknikleri kullanılabilir. Siyalolitlerin teşhisi için ultrasonografi ilk seçenek olarak düşünülebilir. ${ }^{1}$ Siyalolitleri görüntülemek için konvansiyonel radyograflar kullanılacaksa ışınlama süresi yarıya indirilmelidir, böylece daha az kalsifiye olanlar da görüntülenebilir. ${ }^{2}$

\section{Ayırıcı tanı}

Başlıca ayırıcı tanılar; kalsifiye lenf nodları, flebolit gibi vasküler malformasyonlar, myositis ossifikans, lenfanjiom ve hemanjiomlardır. Nadir fakat diğer olası ayırıcı tanılar ise kalsifiye akne, osteoma cutis ve osteoma ile yapılır. Bu tanıların hepsi genellikle multiple olarak gözlenir ve kalsifikasyonlar dağınık yerleşim gösterir. ${ }^{9,14}$

Siyalolit teşhisini en sık yanıltan durum ise kalsifiye lenf nodlarıdır. ${ }^{9}$ Siyalolitler diğer yumuşak doku kalsifikasyonlarından ağrı ve etkilenen bezde şişlik gibi semptomlarla ayrılabilir. Diğer kalsifikasyonlar sıklıkla asemptomatiktir. ${ }^{1-3,9}$ Siyalolitleri vasküler kaynaklı lezyonlardan ayırt etmek için doppler sonografi alınabilir. Kesin tanıya ulaşabilmek için ultrasonografi, sialografi, bilgisayarlı tomografi, sialoendoskopiden de faydalanılabilir. ${ }^{9}$

Tedavi, siyalolitin lokalizasyonuna ve büyüklüğüne bağlı olarak değişiklik gösterir. Küçük ise konservatif tedavi uygulanır. Lokal sıcak uygulama ve masaj ile siyalolit hareket ettirilmelidir. Eğer çok büyükse bezin kanalına kanül yerleştirildikten sonra siyalolitin tam üzerinden insizyon yapılarak çıkarılabilir. ${ }^{1,2}$

\section{Flebolit}

Ven, venül veya hemanjiomların damarlarında oluşan kalsifiye pıhtıdır. ${ }^{1,2,8,9}$

\section{Klinik özellikler}

Flebolit baş-boyun bölgesinde oldukça nadir görülür. Ancak flebolit varlığı, hemanjiom varlığı için bir işarettir. Erişkinlerde flebolitler çocukluk çağında bulunup çok zaman önce gerilemiş bir hemanjiomun kalıntısı 
olabilir. ${ }^{1,2,9}$ Bölgedeki yumuşak dokunun renginde değişiklik gözlenebilir ve yine tabloya şişlik ve zonklama tarzında ağrı da eşlik edebilir. Yumuşak dokuya basınç uygulanması sonucu dokuda beyazlaşma veya renk değişikliği gözlenmesi (diaskopi), durumun vasküler kaynaklı olduğuna dair bir işarettir. ${ }^{1,2}$

\section{Radyografik özellikler}

Yaklaşık $6 \mathrm{~mm}$ çapında, oval veya yuvarlak şekilli çevresi düzgün genellikle 'boğa gözü' gibi lamelli görüntü verse de homojen radyoopak görüntü de gösterebilir..,2,8,9

\section{Ayırıcı tanı}

Flebolitin görünümü bazen siyaloliti andırabilir. Ancak siyalolitler genellikle tek, flebolitler ise çok sayıdadır. Siyalolitler çok sayıda görüldüğünde tek bir hat üzerinde izlenirken, flebolitler rastgele dağılım gösterir. ${ }^{1,2,9}$

\section{Laringeal kıkırdak kalsifikasyonları}

Laringeal kıkırdaklar hyalin kıkırdaktan, epiglottis ve arytenoid kıkırdaklar fibroelastik kıkırdaktan oluşmuştur. Tirohyoid ligamentlerin arasında küçük bir çift triticeous kıkırdak bulunur. Tiroid ve triticeous kıkırdakların her ikisi de hyalin kıkırdak içermektedir ve hyalin kıkırdakların yaşla birlikte kemikleşme ve kalsifiye olma eğilimleri vardır. ${ }^{2,28}$ Özellikle tiroid kıkırdakta olmakla birlikte laringeal kıkırdakların kemikleşmesi genellikle asimetrik olarak meydana gelir. ${ }^{15}$ Triticeous kıkırdaklar, laringeal iskelette yer alan bilateral ovoid yapılardır. Fonksiyonları tam olarak bilinmese de yakın zamanda ortaya atılan görüş tirohyoid ligamenti güçlendirdiği yönündedir..,17,28 Tiroid kıkırdak ise larinks kıkırdaklarının en üstte yer alanı ve aynı zamanda en büyük olanıdır. Tiroid kıkırdağın kalsifikasyonu yaşam boyu devam eder. Genellikle arka sınırdan başlayan kalsifikasyon süreci, tiroid kıkırdağın alt boynuzuna kadar gelir ve yaklaşık 70 yaş civarında kalsifikasyon süreci tamamlanır. ${ }^{8}$ Ahmad ve arkadaşlarının 847 panoramik radyografı değerlendirdiği bir çalışmada, triticeous kıkırdak kalsifikasyonunun prevelansını \%8.6 olarak bulmuştur. Bu oran erkeklerde \%5, kadınlarda \%12 olarak gözlenmiştir. ${ }^{17}$ Triticeous kıkırdak kalsifikasyonuna, genellikle kadınlarda erkeklere oranla daha fazla rastlanmaktadır. ${ }^{30,31}$

\section{Klinik özellikler}

Laringeal kıkırdak kalsifikasyonu radyografik inceleme esnasında tesadüfen karşılaşılan durumlardandır ve herhangi bir klinik bulgusu yoktur. . $^{-4,6}$

\section{Radyografik özellikler}

Panoramik radyograflarda en sık karşılaşılan laringeal kıkırdak kalsifikasyonu; kalsifiye triticeous ve tiroid kıkırdaklardır. Kalsifiye triticeous kıkırdak, panoramik ve lateral kafa grafilerinde hyoid kemiğin büyük boynuzunun altında ve 4. servikal vertebranın üst sınırına komşu bir şekilde izlenir. Triticeous kıkırdağın uzunluğu 7-9 $\mathrm{mm}$ ve genişliği 2-4 mm arasında değişmektedir. Kalsifiye triticeous kıkırdak, çevresi belirgin ve pürüzsüz yapı gösterir. ${ }^{2,25}$ Kalsifiye tiroid kıkırdağın üst boynuzu 4. servikal vertebranın medialinde bulunur ve prever- tebral yumuşak dokuya süperpoze olur. .,8,28 $^{2}$

Kalsifiye laringeal kıkırdak genellikle homojen bir radyoopasite gösterir fakat bazen dış bir korteks izlenebilir. $^{2} 13$ yaş altındaki çocuklarda ve bebeklerde laringeal kıkırdak kalsifikasyonlarının radyolojik bulguları sıklıkla gözlenmez. ${ }^{28}$

\section{Ayırıcı tanı}

Kalsifiye triticeous kıkırdak, karotis bifurkasyonundaki kalsifiye aterosklerotik plak ile karıştırılabilir. Ancak soliter doğası ve homojen yapısı ayırıcı tanıda önemlidir.,2,8,17,28 Kardiovasküler ve serebrovasküler hastalıklar için risk teşkil eden kalsifiye aterosklerotik plakların bu açıdan kalsifiye triticeous kıkırdaklardan ayırt edilmesi son derece önemlidir. ${ }^{17,28}$

Laringeal kıkırdak kalsifikasyonları için herhangi bir tedavi gereksinimi yoktur. ${ }^{28}$

\section{Rinolit-antrolit-dakriyolit}

Antrolit, maksiller sinüste diş kökü, kan pıhtısı, yoğun mukus gibi eksojen kaynaklar sonrası bu bölgeye mineralize tuzların çökelmesiyle oluşan kalsifikasyonlardır. ${ }^{1,2}$ Rinolit, buruna boncuk ve benzeri eksojen maddelerin kaçması sonrası bu bölgede mineralize tuzların çökelmesiyle, dakriyolit ise gözyaşı kanallarında kalsifiye yapıların birikmesiyle oluşur. ${ }^{1,2}$

\section{Klinik özellikler}

Antrolit tablosu, genellikle asemptomatiktir. Tek taraflı rinore, sinüzit, baş ağrısı, epistaksis, anozmi, kötü koku ve ateş gibi semptomlar olabilir.,

Rinolitte, nazal obstrüksiyon ve antrolittekine benzer semptomlar izlenebilir. ${ }^{1}$ Dakriyolit, gözyaşı artışına, gözyaşı bezinin enflamasyonuna ve o bölgenin şişmesine zemin hazırlayabilir. ${ }^{1}$

\section{Radyografik özellikler}

Bu kalsifikasyonlar, nidusun boyutuna bağlı olarak çeşitli şekil ve boyutlara sahiptir. Rinolit ve antrolitler laminasyonlu bir yapı gösterebilir. Homojen veya heterojen radyoopak görüntü verirler. Bazen kemikten daha radyoopak bir yapıda izlenebilir (Resim 6). ${ }^{1,2}$

Ayırıcı tanı

Ayırıcı tanı osteoma, odontoma ve kalsifiye polip ile yapılır. ${ }^{2}$

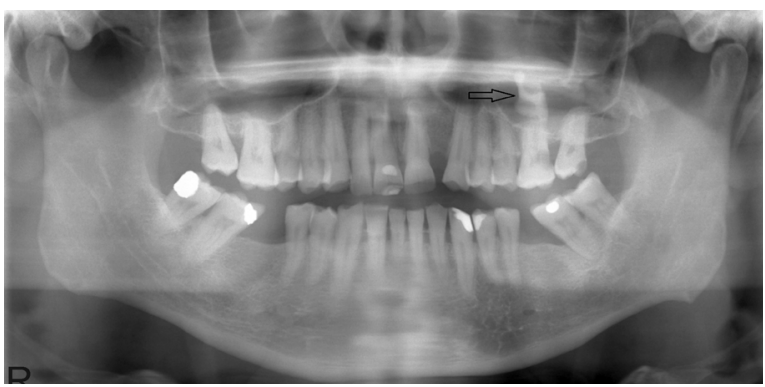

Resim 6. Panoramik radyografta sol maksiller sinüs içerisinde maksiler 1. molar dişin apeksi hizasında antrolit izlenmektedir (ok). 


\section{Metastatik kalsifikasyon}

Serumda artmış kalsiyum ve fosfat seviyesiyle birlikte oluşan kalsifikasyonlardır. Hiperparatiroidizm ve malign hastalıklarda çok nadir gözlenen bir durumdur. ${ }^{1}$

\section{Heterotopik Ossifikasyon}

Kalsiyum tuzlarının organize bir şekilde yumuşak dokuda biriktiği durumlar heterotopik ossifikasyon olarak adlandırılır. ${ }^{1,2}$

\section{Stylohyoid ligament ossifikasyonu}

Styloid zincir, stylohyoid ligament, styloid proçes ve hyoid kemiğin küçük bir bölümünü içeren kemik-bağ doku kompleksidir. ${ }^{7,8}$ İkinci faringeal arktan köken alan Reichert's kıkırdağından gelişir. ${ }^{32}$

Styloid proçes, temporal kemiğin inferior yüzünde, stylomastoid foramenin ön tarafında yer alır. Proçesin normal uzunluğu 20-25 mm olup yukardan aşağıya doğru incelen kuru ağaç dalına benzer bir yapıdır. Styloid proçes, internal ve eksternal karotid arterler arasında uzanır. 1,7,8,32 Styloid proçes ya da stylohyoid ligament kompleksinin toplam uzunluğu $30 \mathrm{~mm}$.'den fazla ise bu durum ossifikasyon olarak değerlendirilir. ${ }^{29}$ Stylohyoid ligamentin ossifikasyonu genellikle bilateral olarak görülür ve kafa tabanının aşağısına doğru uzanır. Ossifikasyon nadir vakalarda hyoidin küçük boynuzundan başlar, yine az sayıda vakada ligamentin ortasından başladığı görülür. ${ }^{8}$ Etiyolojisinde ektopik kalsifikasyonun rol oynadığı düşünülse de kesin mekanizması tam olarak bilinmemektedir. ${ }^{32}$

\section{Klinik özellikler}

Stylohyoid ligament ossifikasyonunun prevalansı \%5 civarında olsa da literatürde daha yaygın gözlendiğini bildiren kaynaklar da vardır. ${ }^{1,8,32}$ Bir çalışmada popülasyonun \%18'inde stylohyoid ligamentin $30 \mathrm{~mm}$ 'den daha fazlasının ossifiye olduğu tespit edilmiştir. ${ }^{2}$ Ossifiye ligament, palpasyonda tonsil üzerinde sert ve noktasal bir yapı olarak tespit edilebilir. Vakaların yaklaşık \%50'si asemptomatiktir. Ancak uzamış styloid proçesin komşu dokulara baskı ve irritasyonu sonucunda disfaji ve faringeal bölgede yabancı cisim hissi oluşabilir. En sık karşılaşılan semptomlardan birisi ağrıdır. Ağrı, çiğneme kasları, kulak bölgesi ve temporomandibular eklemde lokalize olur. 1,2,8,32

Stylohyoid ligament ossifikasyonu ile ilişkili semptomlar Eagle sendromu olarak adlandırılır ve iki alt grubu vardır. $2,7,32$

\section{Klasik Eagle sendromu: Kraniyal sinirlerde sıkışma}

2. Karotis arter sendromu: Karotis arterlerin sıkışması

Hastanın anamnezinde boyun travması (tonsillektomi öyküsü) varsa ve semptomatik ise klasik Eagle sendromu denir. Boyun travması öyküsü olmayan ve klinik semptomların olduğu durum ise karotis arter sendromu olarak adlandırılmaktadır. ${ }^{2}$
Eksternal karotis artere bası olduğunda; hasta suborbital bölgede ağrı hissedebilir. İnternal karotis arter etkilendiğinde ise; göz ağrısı, temporal ya da parietal bölgede baş ağrısı, migren, görme ile ilgili semptomlar, vertigo ya da senkop olabilir. ${ }^{2,32}$ Arterlerin çevresindeki sempatik sinir pleksuslarının mekanik irritasyonu ile ağrı oluşmaktadır. Hastaların çoğu 40 yaşın üzerindedir ve bu sendrom klasik Eagle sendromundan daha yaygın görülmektedir. ${ }^{2}$ Styloid proçesin ya da stylohyoid ligamentin karotid arterleri sıkıştırması sonucunda felç gözlenebilir. Bu durumun gerçekleşmesi styloid proçes ya da ligamentin şekline ve boyutuna bağlıdır. ${ }^{32}$

Panoramik radyograflar styloid proçes ossifikasyonlarının ve varyasyonlarının tespit edilmesinde önemli role sahip olsalar da bu kemiğin boyutunun ve yönünün tespitinde yetersiz kalır. Öte yandan süperpozisyonsuz ve üç boyutlu görüntü sağlayan BT veya KIBT güvenilir bir görüntüleme sağlar. .,10,32 Stylohyoid zincirdeki parsiyel ossifikasyonlar, panoramik radyograflarda gözden kaçabilir ya da kompleksin bir bölümü görüntü alanının dışında kalırsa klinisyeni yanlış tanıya götürebilir. Bu sebeple üç boyutlu görüntü elde edilen KIBT doğru tanı için daha güvenilirdir. $7,8,10$

Okabe ve arkadaşlarının 80 yaş civarındaki hastalarda yaptıkları bir çalışmada stylohyoid proçes ile serum kalsiyum konsantrasyonu arasında anlamlı ilişki bulunmuştur. Serum kalsiyum seviyesi ne kadar yüksekse, stylohyoid proçesin uzunluğunun o kadar fazla olduğu gözlenmiştir. ${ }^{33}$

\section{Radyografik özellikler}

Genellikle panoramik radyograflarda tesadüfen tespit edilir. Panoramik radyografta styloid proçesten başlayıp hyoid kemiğe doğru uzanan çizgisel ossifikasyon olarak izlenmektedir. ${ }^{2}$

Styloid proçes, uzun, konik şekilli, kalın ve radyoopak olarak izlenir. Ossifiye ligamentin düz bir dış hattı vardır, fakat bazen dış yüzeyde düzensizlikler görülebilmektedir. Stylohyoid ligamentin ossifikasyonu hyoid kemiğe kadar uzanabilir (Resim 7). Burada kemikle arasında eklem benzeri bağlantı vardır ve radyolüsent olarak sonlanır. Stylohyoid ligamentte meydana gelen küçük ossifikasyonlar homojen radyoopasite gösterir. Ossifikasyon arttıkça periferi radyoopak bant şeklinde görünür. ${ }^{2}$ Styloid proçes-stylohyoid ligament kompleksinde görülen ossifikasyonlar mandibular foramenin

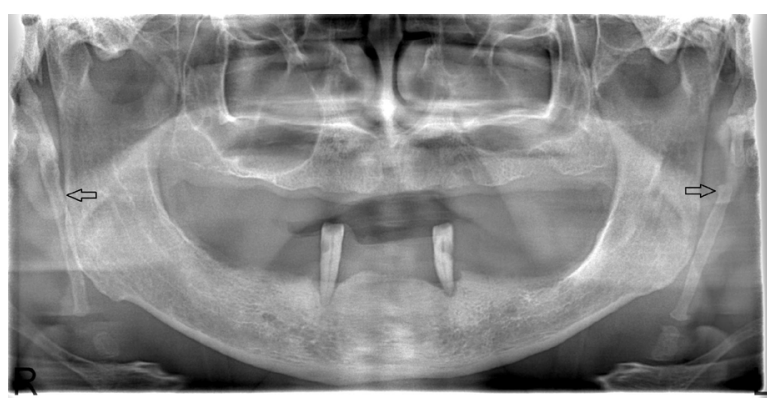

Resim 7. Panoramik radyografta sağ ve sol tarafta styloid proçesten başlayıp hyoid kemiğe uzanan stylohyoid ligament ossifikasyonu izlenmektedir (ok). 
üzerinde ise 'süperior', foramen ve angulus mandibula arasında ise 'orta', angulus mandibulanın altında ise 'inferior' olarak sınıflandırılır.'

\section{Ayırıcı tanı}

Stylohyoid ligament ossifikasyonu, Eagle sendromu ya da stylohyoid sendrom sonucu oluşan semptomlar genellikle tanı koydurucu özellikte değildir. Görüntülerde stylohyoid ligament ossifikasyonu izleniyorsa başka bir rahatsızlık ile karışma intimali çok düşüktür.

Bazen temporomandibular eklem disfonksiyonlarıyla karışabilir. Öğürme refleksi topikal anesteziyle kontrol altına alınıp, tonsiller fossa palpe edilerek sert submukozal kitle aranır. ${ }^{2}$

Çoğunlukla ossifiye stylohyoid ligament asemptomatiktir ve tedavi gerektirmez. Semptomları belli belirsiz olan hastalarda tonsiller fossaya steroid ya da lidokain enjeksiyonu önerilebilir. Semptomları şiddetli olan hastalarda ise stylohyoid proçesin amputasyonu önerilebilir. ${ }^{1,2}$

\section{Osteoma cutis}

Cilt ya da subkutanöz dokular içinde fokal kemik gelişimi sonucu oluşan, nadir görülen bir yumuşak doku kalsifikasyonudur. Herhangi bir etkeni olmadan primer olarak oluşabilir. Yaklaşık \%85 oranında sekonderdir, uzun süredir var olan akne, skar oluşumu ya da kronik enflamatuar dermatozların varlığı sonucu görülebilir. ${ }^{2}$

\section{Klinik özellikler}

Osteoma cutis her yerde oluşabilir fakat en çok yüzde görülür. İntraoral bölgede en çok dilde görülür. Ciltte gözle görülür bir değişikliğe yol açmaz, bazen renk değişikliği yapabilir, sarımsı beyaz olarak görülebilir. Lezyon büyükse palpe edilebilir. Palpe edilen bölgeye iğne batırıldığında sert, taş gibi bir kitle ile karşılaşııır. Kadınlarda özellikle yüz bölgesinde, erkeklerde ise kafa derisi ve göğüs bölgesinde birden fazla lezyon olabilir. ${ }^{2}$

\section{Radyografik özellikler}

Radyografta osteoma cutis en yaygın olarak yanak ve dudak bölgelerinde görülür. Bu bölgelerde görüntü diş köklerine veya alveolar kemiğe süperpoze olarak o bölgede dens kemik görüntüsü verebilir. ${ }^{2}$

Yanak ile alveolar proçes arasına intraoral film yerleştirilerek yalnızca yanağın görüntülenmesiyle süperpozisyon önlenerek, lezyonun gerçek yeri anlaşılabilir. Alternatif olarak hastaya yanağını şişirmesi söylenerek ve yumuşak doku tekniğiyle posteroanterior filmler alınarak ciltteki osteoma cutis lezyonlarının yeri tespit edilebilir.

Osteoma cutis düzgün sınırlı, radyoopak olarak izlenebilir. Bu tek ya da çok sayıda radyoopasiteler genellikle çok küçüktür. Fakat boyutları 0,1-5 cm arasında değişebilmektedir. Homojen radyoopasite gösterebildiği gibi merkezinde yağlı kemik iliği varlığına bağlı olarak genellikle radyolüsent bölge bulunur. Büyük lezyonlarda kemik iliğinde de trabekülasyon oluşur. Kalsifiye kistik akne lezyonları, ciltte skar dokusu olan bölgelere karşılık gelen yerlerde kar tanesine benzer radyoopasite gösterir. $^{2}$

\section{Ayırıcı tanı}

Myositis ossifikans, kalsinozis cutis ve osteoma mukoza ayırıcı tanıda düşünülmelidir. Hastanın yanağını şişirmesi ile alınan radyografta osteoma cutis lezyonları mukozal lezyonlardan çok daha yüzeyel görülür. Myositis ossifikans büyük boyutlardadır ve bazı vakalarda fasiyal deformite yapabilir. ${ }^{2}$

Tedavi gerektirmez fakat primer osteoma cutisler bazen estetik sebeplerle çıkarılır. ${ }^{2}$

\section{Myositis ossifikans}

Myositis ossifikans, iskelet kası içinde kemik ve kartilaj doku oluşumudur. Maksillofasiyal bölgede en sık masseter, temporal ve pterygoid kaslarda görülür.1,34-36

Myositis ossifikans'ın patogenezi tam olarak belli değildir. En yaygın kabul gören teori, travma veya cerrahi yaralanmayı takiben ekstraosseöz hücrelerin kemik morfojenik proteinlere farklılaşmasıdır. ${ }^{35}$ Iki formu vardır: 1) Lokalize (travmatik), 2) Progresif

\section{Lokalize (travmatik) myositis ossifikans}

'Posttravmatik myositis ossifikans' ya da 'soliter myositis' de denilmektedir. Akut ya da kronik travma, ağır kas gerilmesine sebep olan sporların yapılması gibi sebeplerle oluşur. Aynı bölgeye çok sayıda enjeksiyon yapılması (örn. dental anestezi sırasında) sebebiyle oluşan kas zedelenmesi de myositis ossifikans sebebi olabilir. ${ }^{1,2,34,35}$

Önemli derecede fiziksel travma sonucunda iskelet kaslarının sınırlı rejenerasyon kapasitesi vardır. Yaralanma sonucunda oluşan vasküler hemoraji, iyileşme sırasında kartilaj ve kemiğe dönüştüğünde myositis ossifikansa neden olur. 'Myositis' terimi yanıltıcıdır çünkü enflamasyon yoktur. Aslında gerçek bir ossifikasyon da yoktur, kas içindeki dokular arasında fibröz doku ve kemik formasyonu vardır. ${ }^{2,35}$

Literatürde 2001 yılından 2014 yılına kadar olan vakaları inceleyen bir derlemede, çiğneme kaslarını etkileyen myositis ossifikans, yaşları 18 ile 68 arasında değişen, 20 farklı vakada gözlenmiştir. Bu 20 hastanın 19'unun başvuru şikayeti ağız açıklığında kısıtııık olmuştur. Hastaların 8'inde yüz bölgesine travma, 6'sında lokal anestezi infiltrasyonu, 1'inde cerrahi işlem, 1'inde alkol infiltrasyonu öyküsü saptanmış olup hastaların 4'ünde olası hiçbir neden bulunamamıştır. ${ }^{36}$

\section{Klinik özellikler}

Her yaşta görülebilir, cinsiyet ayrımı yapmaz fakat genellikle sporla uğraşan genç erkeklerde sık görülür. Travma alan bölgede şişlik ve şiddetli ağrı vardır. Üzerindeki cilt kızarık ve enflame olabilir. Lezyon çiğneme kaslarını içerirse ağız açmada güçlük yaşanabilir. ${ }^{1,2,35}$ 
Travmadan yaklaşık 2 ya da 3 hafta sonra intramüsküler kitle palpe edilebilir. Lokalize lezyon yavaş büyüme gösterebilir fakat genellikle büyümez. Palpasyonda hareketli ya da fikse olabilir., ${ }^{1,2}$ Pozisyonundan dolayı travmadan en sık massater kası etkilenir Bunu temporal kas ve medial pterygoid kas takip eder. ${ }^{35,36}$ Laboratuvar testleri genellikle normal sınırlar içindedir. Ancak bazı vakalarda serumda yüksek alkalen fosfataz seviyesi bildirilmiştir ${ }^{35}$

\section{Radyografik özellikler}

Baş ve boyun bölgesinde en çok etkilenen kaslar masseter ve sternokleidomastoid'dir. Fakat medial ve lateral pterygoid, buksinatör ve temporal kaslar da etkilenebilmektedir. ${ }^{2}$

Ossifikasyon bölgesi ve komşu kemik dokusu arasında genellikle radyolüsent bant izlenmektedir. Kitleler genellikle 6 cm'den küçüktür. ${ }^{2}$

Travmadan 3-4 hafta sonra radyoopasite oluşmaya başlar ve yaklaşık 2 ay sonra radyoopak internal yapılar belirginleşir. Bu değişiklik kemik yapımını göstermektedir fakat buradaki kemik normal trabeküler yapıda kemik değildir. Yaklaşık 5-6 ay içerisinde lezyonun maturasyonu tamamlanır ve homojen radyoopak olarak görülür. Bazı lezyonlar çok yavaş gelişir ve maturasyonun tamamlanması 12 ayı bulabilir. Bu periyottan sonra lezyonda küçülme izlenebilir. ${ }^{2}$

Doğru tanı ve tedavi planlaması için Bilgisayarlı Tomografi en temel görüntüleme yöntemidir. ${ }^{35}$

\section{Ayırıcı tanı}

Stylohyoid ligament ossifikasyonu ve diğer yumuşak doku kalsifikasyonlarıyla yapılmalıdır. Myositis ossifikansın formu ve yeri genellikle ayırıcı tanıda yeterlidir. Osteojenik sarkom gibi tümörlerde çizgisel kemik yapımı görülebilmektedir, fakat bu tümör kemiğe bitişiktir ve genellikle kemik yıkımı vardır. ${ }^{2}$

Tedavi seçenekleri kalsifiye kitlenin eksizyonu veya lezyonun gelişimi sırasında kemik morfogenetik protein tip 1 inhibitörü verilerek heterotopik ossifikasyonun durdurulmaya çalışılmasıdır. ${ }^{35,36}$ Bu sırada hastaya dinlenme ve ilgili bölgenin kullanımını sınırlaması önerilir. Fonksiyonel kısıtlama ya da nörolojik bozukluğa yol açan lezyonların tamamının cerrahi eksizyonu ve cerrahi sonrası skar oluşumunu en aza indirmek için fizyoterapi önerilmektedir. ${ }^{2}$

Progresif myositis ossifikans'tan farklı olarak cerrahi eksizyon sonrasında iyileşme sağlanır ve nüks oldukça nadirdir. ${ }^{35}$

\section{Progresif myositis ossifikans}

'Fibrodisplazi ossifikans progresif' de denilmektedir. Otozomal dominant olarak aktarılan, nadir görülen, herediter bir hastalıktır. Bazen genlerdeki spontan mutasyon sonucu da oluşabilir. ${ }^{2,36}$ Erkeklerde daha yaygın olarak görülür ve semptomları erken bebeklik döneminde ortaya çıkar. ${ }^{2}$

\section{Klinik özellikler}

Çoğu vakada heterotopik ossifikasyon boyun kaslarından başlar ve ekstremitelere yayılır. Hastalık yumuşak dokuda şişlik ile başlar, ağrılıdır, kızarıklık ve ısı artışı da gösterebilir. Akut durum geçtiğinde dokular arasında sert kitle kalır. Bu durum kalp ve diyafram dahil tüm çizgili kasları etkileyebilir. Bazı vakalarda ossifikasyonun yayılımı sınırlıdır, bazılarında ise vücutta neredeyse tüm büyük kasları etkilemektedir. Lezyonun sertliği, boyun, göğüs ve ekstremitelerin hareket kısıtııı̆ı dereceli olarak artmaktadır. Lezyonun ileri evrelerinde 'taşlaşmış adam' olarak tanımlanan durum oluşur. Üçüncü dekatta proçes spontan olarak durabilir, fakat çoğu hasta üçüncü veya dördüncü dekatta yaşamını yitirmektedir.

\section{Radyografik özellikler}

Radyografik özellikleri lokalize tipi ile benzerlik gösterir.

\section{Ayırıcı tanı}

Başlangıç evresinde romatoid artrit ile ayırıcı tanısını yapmak güçtür. Efektif tedavisi yoktur. Travmatize ve ülsere olmuş nodüllerin eksizyonu önerilir. İleri evrelerde solunum sistemi ile ilgili problemler gelişirse destekleyici tedavi gerekebilir. ${ }^{2}$

\section{SonUç}

Sonuç olarak; yumuşak doku kalsifikasyonları/ossifikasyonları genellikle radyografik muayene sırasında tesadüfen saptanır. Hekimler, yumuşak doku kalsifikasyonlarını tanıyabilmeli ve bölgedeki mevcut anatomik yapılardan ve patolojilerden ayırt edebilmelidir. Gerekli durumlarda ileri tetkikler için hastaların yönlendirilmesi oldukça önemlidir.

Çıkar çatışması: Yazarlar bu çalışmayla ilgili herhangi bir çıkar çatışmalarının bulunmadığını bildirmişlerdir.

\section{KAYNAKLAR}

1. Harorlı A. Ağız Diş ve Çene Radyolojisi, 1. baskı. İstanbul: Nobel; 2014.

2. Carter LC. Soft tissue calcifications and ossifications. White SC, Pharoah MJ, eds. Oral Radiology: Principles and Interpretation. St. Louis, MO: Mosby Elsevier; 2014. p.524-41.

3. Garg AK, Chaudhary A, Tewari RK, Bariar LM, Agrawal N. Coincidental diagnosis of tuberculous lymphadenitis: a case report. Aust Dent J 2014;59:258-63

4. Garay I, Netto HD, Olate S. Soft tissue calcified in mandibular angle area observed by means of panoramic radiography. Int J Clin Exp Med 2014;7:51-6

5. Thakur JS, Minhas RS, Thakur A, Sharma DR, Mohindroo NK. Giant tonsillolith causing odynophagia in a child: A rare case report. Cases J 2008;1:50

6. Friedlander $\mathrm{AH}$, Friedlander IK. Identification of stroke prone patients by panoramic radiography. Aust Dent J 1998;43:51-4.

7. Centurion BS, Imada TS, Pagin O, Capelozza AL, Lauris JR, RubiraBullen IR. How to assess tonsilloliths and styloid chain ossifications on cone beam computed tomography images. Oral Dis 2013;19:473-8.

8. Scarfe WC, Farman AG. Soft tissue calcifications in the neck: Maxillofacial CBCT presentation and significance. AADMRT Currents 2010;2:1-15. 
9. Bar T, Zagury A, London D, Shacham R, Nahlieli O. Calcifications simulating sialolithiasis of the major salivary glands. Dentomaxillofac Radiol 2007;36:59-62.

10. Takahashi A, Sugawara C, Kudoh T, Uchida D, Tamatani T, Nagai $\mathrm{H}$, et al. Prevalence and imaging characteristics of palatine tonsilloliths detected by CT in 2,873 consecutive patients. ScientificWorldJournal 2014;2014:940960

11. Monsour PA, Romaniuk K, Hutchings RD. Soft tissue calcifications in the differential diagnosis of opacities superimposed over the mandible by dental panoramic radiography. Aust Dent J 1991;36:94-101.

12. Alattar MM, Baughman RA, Collett WK. A survey of panoramic radiographs for evaluation of normal and pathologic findings. Oral Surg Oral Med Oral Pathol 1980;50:472-8.

13. Barrett AP, Waters BE, Griffiths CJ. A critical evaluation of panoramic radiography as a screening procedure in dental practice. Oral Surg Oral Med Oral Pathol 1984;57:673-7.

14. Valiyaparambil J, Rengasamy K, Mallya SM. An unusual soft tissue radiopacity - radiographic appearance of a dermal filler. $\mathrm{Br}$ Dent $\mathrm{J}$ 2009;207:211-2.

15. Keberle M, Robinson S. Physiologic and pathologic calcifications and ossifications in the face and neck. Eur Radiol 2007;17:2103-11.

16. Kamikawa RS, Pereira MF, Fernandes A, Meurer MI. Study of the localization of radiopacities similar to calcified carotid atheroma by means of panoramic radiography. Oral Surg Oral Med Oral Pathol Oral Radiol Oral Endod 2006;101:374-8.

17. Ahmad M, Madden R, Perez L. Triticeous cartilage: Prevalence on panoramic radiographs and diagnostic criteria. Oral Surg Oral Med Oral Pathol Oral Radiol Oral Endod 2005;99:225-30.

18. Singh A, Rahman H, Kumar V, Anila F. An unusual case of paradoxical enlargement of lymph nodes during treatment of tuberculous lymphadenitis in immunocompetent patient and literature review. Am J Case Rep 2013;14:201-4.

19. Shubha $A B$, Hegde $S$, Dinesh RB. Tuberculous lymphadenitis presenting a diagnostic dilemma- a case report. Int $\mathrm{J}$ Dent Clin 2010;2:48-52.

20. Eisenkraft BL, Som PM. The spectrum of benign and malignant etiologies of cervical node calcification. AJR Am J Roentgenol 1999;172:1433-7.

21. Çakur B, Yıldırım E, Demirtaş Ö. Panoramik radyografide tonsil taşı ve karotis arter kalsifikasyonu arasındaki ilişkinin incelenmesi. Atatürk Üniv Diş Hek Fak Derg. 2014;24:1-5.

22. Aspestrand $F$, Kolbenstvedt $A$. Calcifications of the palatine tonsillary region: CT demonstration. Radiology 1987;165:479-80.

23. Ertas ET, Sisman Y. Detection of incidental carotid artery calcifications during dental examinations: panoramic radiography as an important aid in dentistry. Oral Surg Oral Med Oral Pathol Oral Radiol Endod 2011;112:e11-7.

24. Friedlander $\mathrm{AH}$, Lande $\mathrm{A}$. Panoramic radiographic identification of carotid arterial plaques. Oral Surg Oral Med Oral Pathol 1981;52:102-4

25. Freymiller EG, Sung EC, Friedlander AH. Detection of radiationinduced cervical atheromas by panoramic radiography. Oral Oncol 2000;36:175-9

26. Sisman Y, Ertas ET, Gokce C, Menku A, Ulker M, Akgunlu F. The prevalence of carotid artery calcification on the panoramic radiographs in Cappadocia region population. Eur J Dent 2007;1:132-8.

27. Bayram B, Uckan S, Acikgoz A, Muderrisoglu H, Aydinalp A. Digital panoramic radiography: a reliable method to diagnose carotid artery atheromas? Dentomaxillofac Radiol 2006;35:266-70.
28. Carter LC. Discrimination between calcified triticeous cartilage and calcified carotid atheroma on panoramic radiography. Oral Surg Oral Med Oral Pathol Oral Radiol Oral Endod 2000;90:108-10.

29. Lee JS, Kang BC. Screening panoramic radiographs in a group of patients visiting a Health Promotion Center. Korean J Oral Maxillofac Radiol 2005;35:199-202.

30. Ajmani ML, Jain SP, Saxena SK. A metrical study of laryngeal cartilages and their ossification. Anat Anz 1980;148:42-8

31. O'Bannon RP, Grunow $\mathrm{OH}$. The larynx and pharynx radiologically considered. South Med J 1954;47:310-6.

32. Gokce C, Sisman Y, Sipahioglu M. Styloid process elongation or Eagle's Syndrome: is there any role for ectopic calcification. Eur J Dent 2008;2:224-8.

33. Okabe S, Morimoto Y, Ansai T, Yamada K, Tanaka T, Awano S et al. Clinical significance and variation of the advanced calcified stylohyoid complex detected by panoramic radiographs among 80 year-old subjects. Dentomaxillofac Radiol 2006;35:191-9.

34. Kanlı A, Özkan G. Yumuşak dokuda radyoopak görüntü veren lezyonlar. Turkiye Klinikleri J Dental Sci-Special Topics 2010;1:58-65.

35. Boffano P, Zavattero E, Bosco G, Berrone S. Myositis ossificans of the left medial pterygoid muscle: case report and review of the literature of myositis ossificans of masticatory muscles. Craniomaxillofac Trauma Reconstr 2014;7:43-50.

36. Jiang Q, Chen MJ, Yang C, Qiu YT, Tian Z, Zhang ZY, et al. Postinfectious myositis ossificans in medial, lateral pterygoid muscles: $A$ case report and review of the literature. Oncol Lett 2015;9:920-6.

\section{Soft tissue calcifications and ossifications: review}

\section{Abstract}

Deposition of the minerals in soft tissue which normally accumulates in bone is known as calcification/ossification. These calcifications are generally asymptomatic and are seen mostly at elder ages. Typically, they are detected as incidental findings during radiographic evaluation. When these calcifications/ossifications are seen, primary purpose is to identify and specify whether treatment is necessary. For differential diagnosis, criteria such as Iocalization, number and shape should be considered, and a thorough knowledge of soft tissue anatomy is essential. Additionally, it is beneficial to detail the anamnesis and the clinical examination, and if necessary, take additional radiographs from different angles or using different techniques. The purpose of this review was to discuss the current literature regarding soft tissue calcifications and ossifications.

KeywordS: Carotid arteries; ossification, heterotopic; panoramic radiography; salivary gland calculi 